\title{
THE ATROPHIED RULE-MAKING POWERS OF THE NATIONAL LABOR RELATIONS BOARD
}

\author{
GORNELIUS J. PEGK $\dagger$
}

THE days of the National Labor Relations Board have never been peaceful. Even the most cautious person may safely predict that it will be a long time, if ever that time should come, before the business of the NLRB will settle down to a quiet state of affairs. The Board regulates an area of our society in which economic pressures are tremendous, personal convictions are strongly held, and political significance is easily attached to actions taken. Moreover, the experimental Wagner Act, ${ }^{1}$ which it was given to administer in 1935 , has since been twice subjected to major revisions-once by the Taft-Hartley Act of 1947,2 and more recently by the Labor-Management Reporting and Disclosure Act of $1959 .^{3}$ In each case competing forces have produced legislative compromises whose ambiguities constitute the seeds for future controversies. ${ }^{4}$ Broad policy questions demand solution and present opportunities for debate on substantive issues of great importance.

It is, then, with reservation that one undertakes a critical analysis of a procedural matter: the Board's failure to utilize its rule-making powers. Nevertheless, recent developments make it appear appropriate to do so.

This subject is, of course, only one of the procedural matters which have drawn the attention of lawyers familiar with the activities of the Board. In 1958 the American Bar Association's Labor Law Section, with the approval of the Association's House of Delegates, made seven general recommendations for changes in NLRB procedures. ${ }^{5}$ Among the recommendations which the Labor Law Section made to the Board was:

The Board should reconsider its view that its decisional policies on such matters as jurisdictional standards and contract-bar rules do not come within the rule-making requirements of the Administrative Procedure Act. ${ }^{6}$

$\dagger$ Professor of Law, University of Washington.

1. NLRA, 49 Stat. 449 (1935), as amended, 29 U.S.C. $\$ \S 151-68$ (1958), as amended, 29 U.S.C. \$§ 153-87 (Supp. I, 1959).

2. 61 Stat. 136 (1947), as amended, 29 U.S.C. $\$ \$ 141-87$ (1958), as amended, 29 U.S.C. $\S \S 153-87$ (Supp. I, 1959).

3. NLRA, 73 Stat. 519 (1959), 29 U.S.C. $\S \S 153,158-60,187,401-531$ (Supp. I, 1959). Other relatively minor amendments have been made. 63 Stat. 880 (1949); 65 Stat. 601 (1951).

4. See NLRB v. Teamsters Union, 362 U.S. 274, $289-90$ (1960). See also, Cox, The Landrum-Griffin Amendments to the National Labor Relations Act, 44 MINN. L. REv. 257,266 (1959).

5. 42 LAB. REL. REP. 492,513 (1958).

6. 42 LAB. ReL. Rep. 513 (1958). 
A special committee of the Labor Law Section was appointed to work with the Board in bringing about a resolution of the difficulties which led to both this and the other recommendations.

Summarized, the Board's response to the rule-making criticism was that while the Board has afforded the public a large measure of participation in its policy-making activities by inviting the filing of amicus briefs by interested parties, the Board's procedures are designed primarily to develop policy in connection with adjudication and the decision of actual cases. Accordingly, the Board believed no alteration in its rule-making activities to be necessary.7 This constituted but a slight change from the Board's 1956 view of its functions which it stated in reply to the inquiry made by the House Subcommittee on Government Operations, then studying Administrative Organization Procedure and Practice. At that time the Board's view was that it had

uniformly regarded itself as essentially a quasi-judicial rather than a rulemaking agency. The Board, therefore, like the courts, has not made it a practice to issue broad invitations to representatives of labor, industry, or the public generally to submit their views regarding a proposed decision even though many of its decisions have an impact far beyond their impact on the parties involved. ${ }^{8}$

While the Board's reply to the American Bar Association reflects some change in attitude toward the desirability of briefs amicus curiae, the belief expressed upon an earlier occasion no doubt still prevails.

Broad public participation would necessarily involve delay and diffusion of issues in disposition of specific cases, contrary to sound judicial practice and the special need for speedy resolution of labor disputes brought to the Board for determination. ${ }^{9}$

Indeed, the ABA Section, with the approval of the House of Delegates, reached the conclusion that nothing was to be gained by additional efforts to work with the Board, and that the Association should, instead, direct its efforts to obtaining remedial action by legislation. ${ }^{10}$

The Board's conclusion that it does not engage in rule-making activities, but that instead it limits its activities to the ad hoc resolution of issues in the particular cases coming before it, is demonstrably wrong. The related conclusion of the Board, that the rule-making processes are not adaptable to work of the

7. 45 LAB. REL. REP. 407, 409 (1959).

8. Staff of House Committee on Governarent Operations, 85th Cong., 1st Sess., Survey and Study of Adarinistrative Organization, Procedure, and Practice in the Federai Agencies-Agency Response to Questionnaire 1811 (Comm. Print 1957).

9. Ibid.

10. 45 LAB. ReL. Rep. 407 (1959), 46 A.B.A.J. 455 (1960); 46 LAB. ReL. REP. 343 (1960). See also 44 L.R.R.M. 26 (1958), and Report of Proceedings of the Section of Labor Relation Law, 1959, pp. 116-25. Activities of the Board in rule-making were also subjected to the criticism of committees of the Administrative Law Section of the American Bar Association. See Berger, Report of the Committee on Agency Rule-making, 11 AD. LAW BuLt. 275, 280 (1959). 
nature which it performs, is refuted by analysis of its recent activities. This analysis indicates that rule-making is exactly what the Board has engaged in, although without compliance with the requirements of the Administrative Procedure Act or the beneficial support of its statutory authorization to adopt substantive rules. The Board's failure to use rule-making procedures may have been the cause of some of its recent difficulty in securing judicial acceptance of newly promulgated doctrines. Greater difficulties are foreseeable unless a change is made. In addition, the Board's restriction of its activities to the ad hoc or quasi-judicial form has caused it to forego the substantial benefits which may be derived from an intelligent combination of adjudication and rule making.

Finally, the NLRB's attempt to limit its activities to a quasi-judicial form of activity provides an operating model for those who wish to consider the much discussed question of whether the administrative process should be further judicialized. While judicialization has long been the objective of a portion of the bar, in recent years the proposal has gained support in the recommendations made by the Second Hoover Commission ${ }^{11}$ and the American Bar Association ${ }^{12}$ that an administrative court be established. Within the last year the controversial subject figured in a significant debate appearing in the pages of this Journal, in which Louis J. Hector, former CAB Commissioner, advocated a fractionalization of the adminstrative process along the line of the traditional separation of powers concept. ${ }^{13}$ In reply, Earl W. Kintner, Chairman of the Federal Trade Commission, argued that policy could best be devised and implemented by an agency which combined and utilized those powers in an intelligent fashion. ${ }^{14}$

Within the last three months the already famous Landis Report ${ }^{16}$ was issued, containing a powerful argument that the real issue presented in the problem of policy formulation is not whether the planning function should be transferred from administrative agencies to the executive or some other authority. Recognizing that some functions which are more truly planning than adjudicative have been forced into the latter mold, the report acknowledges the

11. Commission on Organization of the Executive Branch of the Government, Report on Legal Sernices aNd Procedure 87-88 (1955). With respect to the activities of the NLRB, the recommendation was tempered with the additional recommendation that Congress study whether the Labor Section of the Administrative Court should have original or appellate jurisdiction.

12. 42 A.B.A.J. 370,374 (1956).

13. Hector, Problems of the $C A B$ and The Independent Regulatory Commissions, 69 YALE L.J. 931 (1960).

14. Kintner, The Current Ordeal of the Adninistrative Process: In Reply to Mr. Hector, 69 Y YLE L.J. 965 (1960). See also, Berger, Removal of Judicial Functions from Fedcral Trade Commission to a Trade Court: A Reply to Mr. Kintner, 59 MICH. L. REv. 199 (1960).

15. Subcommittee on Admintstrative Practice and Procedure of the Senate Committee on the Judiciary, 86tr Cong., 2D Sess., Report on Regulatory Agencies to the President-Elect (Comm. Print 1960). 
value to those formulating policy of the information and knowledge which can be acquired in the process of adjudication. The issue is seen instead as being how the planning function may be conferred upon persons with the capacity and time to discharge that function, using flexible procedures in their search for ideas and policies. ${ }^{16}$ Indeed,with respect to the NLRB, not only was the suggestion of a further separation of functions rejected, but instead the recommendation was made that the separation effected by the Taft-Hartley Act between the Board and the General Counsel be abolished. ${ }^{17}$

The conclusions to be drawn on these broader problems of judicialization and policy formulation from analysis of the Board's experience must, of course, be tempered with a realization that that experience is largely the product of the Board's own peculiar situation. The statute which it administers, the interests which it regulates, and even the men who staff it as well as the rapidity with which changes occur weigh heavily in an evaluation of the procedures followed. Nevertheless, some conclusions of general import may be reached.

\section{Rule-Making under the Administrative Procedure Act}

The NLRB has issued no formal rules other than those governing the practice and procedure to be followed in cases brought before the agency. This is not for lack of statutory authorization to make substantive rules. On the contrary, section 6 of the National Labor Relations Act ${ }^{18}$ specifically provides:

The Board shall have authority from time to time to make, amend, and rescind in the manner prescribed by the Administrative Procedure Act, such rules and regulations as may be necessary to carry out the provisions of this Act.

The Board does not deny that this authorization is broad enough to encompass substantive rule-making powers which its words appear to include. ${ }^{10}$ Indeed, what there is in the legislative history of the Taft-Hartley Act indicates that the present language of the section was adopted in favor of other language which might have deprived the Board of substantive rule-making powers. ${ }^{20}$

16. Id. at $18-19$.

17. Id. at $58-64$.

18. 49 Stat. 452 (1947), 29 U.S.C. § 156 (1958).

19. Staff of House Comaittee on Government Operatrons, 85th Cong., 1st Sess., Survey and Study of Adasinistrative Organization, Procedure, and Practice in the Federal Agencies-Agency Response to Questionnaire 1812 (Comm. Print 1957).

20. Section 6 of the Fouse version of the Taft-Hartley Act as originally reported, H.R. 3020, 80th Cong., 1st Sess. (1947), provided:

The Board and the Administrator, respectively, shall have authority from time to time, in the manner prescribed by the Administrative Procedure Act, to make, amend, and rescind such regulations as may be necessary to carry out their respective functions under this Act.

This provision differed from the equivalent provision of the Wagner Act in its reference to the Administrative Procedure Act and elimination of the authority to make "rules" as 
Instead, the Board's rejection of the rule-making process is apparently based upon the conclusion that this procedure is not adaptable to the work which the Board performs. ${ }^{21}$

An understanding of what forthright rule-making by the Board would involve requires a brief survey of the pertinent provisions of the Administrative Procedure Act. ${ }^{22}$ First, what is a rule and what is rule-making are defined in Section 2(c) of the Act:

"Rule" means the whole or any part of any agency statement of general or particular applicability and future effect designed to implement, interpret, or prescribe law or policy or to describe the organization, procedure, or practice requirements of any agency ... "Rule-making" means agency process for the formulation, amendment, or repeal of a rule. ${ }^{23}$

Much of what is thus defined as rule-making is exempt by other provisions from the procedural requirements established by the Act for the rule-making process. Thus, the Board's interpretative rules, general statements of policy, rules of agency organization, procedure, or practice, rules relating to agency management or personnel, are exempt. ${ }^{24}$

The procedural requirements which are imposed on the nonexempt aspects of rule-making are not oppressive or burdensome. It would be necessary for the Board to publish general notice of the proposed rule-making in the Federal Register, setting out the time and place of the proceedings, reference to the portion of the National Labor Relations Act under which the rule was proposed, and the terms or substance of the contemplated rule. ${ }^{25}$ The Act does not require an adversary or trial type hearing, or even the reception of oral testimony or views. All that would be required of the Board would be an opportunity for interested persons "to participate in rule making through sub-

opposed to regulations. The majority of the House Committee on Labor Education did not mention this change in their report. However, the minority members saw it as an attempt to deprive the Board of the authority to make substantive rules. They said,

Under section 6 of the bill the Board and the Administrator are authorized to prescribe regulations as may be necessary in the manner provided for by the Administrative Procedure Act. This is a limitation upon the present authority of the Board under the National Labor Relations Act "to make, amend, and rescind such rules and regulations" as may be necessary to carry out its duties. ... It seems clear that it is the intent of the authors to eliminate the statutory authority of the Board to issue, in addition to procedural regulations, substantive changes which under the Administrative Procedure Act might be construed as "substantive rules."

H.R. REP. No. 245, 80th Cong., 1st Sess. 75 (1947).

From the reinsertion of the authority to make "rules" as opposed to regulations, one may infer an intent to preserve substantive rule-making power. The matter is not, however, the subject of comment in the Conference Report.

21. Note 8 supra.

22. 60 Stat. 237 (1946), 5 U.S.C. $\$ \S 1001-11$ (1958).

23. 60 Stat. 237 (1946), 5 U.S.C. $\$ 1001$ (c) (1958).

24. 60 Stat. 238 (1946), 5 U.S.C. $\S 1003$ (a) (1958).

25. Ibid. 
mission of written data, views, or arguments with or without opportunity to present the same orally ...." 26 The effective date of rules so adopted would have to be as least 30 days after their publication in the Federal Register, unless the Board found good cause for establishing an earlier effective date. ${ }^{27}$ But, aside from this, no other restraints would be imposed upon the Board, nor would the Board be compelled to follow detailed techniques utilized by other agencies. Indeed, as Professor Davis says,

The federal APA makes no attempt to produce uniformity of rule-making procedures. Instead, it provides minimum standards for party participation, not going beyond the requirement of opportunity to make written presentation and to "appear." 28

In short, the Act would impose but slight burdens if the Board decided to allow the parties who are to be affected by a rule to participate in a limited way in its formulation. The absence of detailed prescriptions affords a freedom and flexibility for the formulation of policy pursuant to procedures designed for the particular occasion and problem. Perhaps the only objection to rulemaking which has an appearance of validity is that of the delay which results from giving interested persons the opportunity to present views as well as from suspending the effectiveness of rules for thirty days after publication. This objection deserves consideration.

Of course, policy formulation could not be eliminated from the Board's adjudicatory processes merely by the adoption upon certain occasions of formal rule-making procedures. The traditional tripartite classification of governmental powers is a great assistance in the analysis of problems, but it cannot change the nature of those problems. Though the definitions of the Administrative Procedure Act might suggest otherwise, rule-making and adjudication do not constitute separate, distinct, and unblendable aspects of governmental activity; on the contrary, upon occasions they are inseparable and merged aspects of the same problem. Even courts, which certainly exemplify the judicial process, formulate policy in the course of adjudication, through the implementation of a statutory purpose as well as in judicial legislation filling in gaps left by legislative oversight. But for the most part they attempt to limit their policy formulation by adherence to precedent, avoiding as undesirable dictum any policy pronouncement beyond that necessary for disposition of the case. Change normally falls within the province of the legislature. On the other hand, rules though stated in general terms and given only future effect may affect only one or so few parties as to take on the appearance of adjudication. Inability to classify all problems as presenting only an occasion for adjudication or rule-

26. 60 Stat. 239 (1946), 5 U.S.C. $\$ 1003$ (b) (1958). This section of the Administrative Procedure Act does make the sections governing adjudication applicable to rule-making proceedings which are required by statute to be made on a record after agency hearing, but there is no such requirement of a record hearing in the National Labor Relations Act.

27. 60 Stat. 238 (1946), 5 U.S.C. $\S \S 1002(a), 1003$ (c) (1958).

28. 1 Davis, Administrative Law $\$ 6.01$, at 360 (1958) [hereinafter cited as Davis]. 
making need not, however, lead to abandonment of the distinction. Used intelligently, the distinction set up in the Administrative Procedure Act offers great assistance in determining how to proceed in most cases. The determination of how changes should be made certainly involves a different set of considerations for an administrative agency than it does for a court. For either, however, failure to heed the distinction may result in problems being handled in the wrong way.

\section{Jurisdictional Rule-Making}

As originally enacted, the National Labor Relations Act empowered the Board to prevent any person from engaging in any unfair labor practice "affecting commerce."29 In a relatively short time it became clear that Congress had thereby exercised the full extent of its powers to regulate commerce, making the test of the Board's jurisdiction whether the effect of an employer's activities on interstate commerce could be said to be de minimis. ${ }^{30}$ The Board, however, both from lack of funds and the necessity of concentrating its efforts upon the most important problems, has never exercised the full extent of its powers. Accordingly, during the first years of the act the questions which constantly recurred were whether the activities of a particular employer "affected" commerce, and, if so, whether it would effectuate the policies of the act for the Board to assert its jurisdiction in that case. This problem was handled on an ad hoc case-by-case basis, subject, of course, to the control which developing precedents played. In October, 1950, however, the Board handed down a series of unanimous decisions setting forth the standards which would govern the future exercise of its jurisdiction. Its avowed purpose was to avoid the necessity of Board consideration of these matters on an individual basis. The decisions were said to be the result of a long study of the pattern emerging from past decisions. ${ }^{31}$ Hence, they might be considered more in the nature of a codification of the existing law than, in the language of the Administrative Procedure Act, "the formulation, amendment, or repeal" of agency policy. In any event, it does not appear that interested parties were invited to participate in the formulation of these standards.

On July 1 and 15, 1954, the Board issued two press releases establishing new and detailed standards for determining whether the Board would assert

29. NLRA, \& 10, 49 Stat. 453 (1935), 29 U.S.C. 160 (a) (1958). Commerce was defined as meaning "... trade, traffic, commerce, transportation, or communication among the several States, or between the District of Columbia or any Territory of the United States and any State...." Affecting commerce was defined to mean "... in commerce, or burdening or obstructing commerce or the free flow of commerce, or having led or tending to lead to a labor dispute burdening or obstructing commerce or the free flow of commerce." NLRA, §§ 2(6), -(7), 49 Stat. 450 (1935), 29 U.S.C. $\S \S 152(6),-(7)(1956)$.

30. NLRB v. Fainblatt, 306 U.S. 601, 608 (1939); cf. NLRB v. Jones \& Laughlin Steel Corp., 301 U.S. 1 (1937).

31. 15 NLRB ANN. REP. 5 (1950). 
its jurisdiction in the future. ${ }^{32}$ The new standards were said to be based upon a study and reappraisal of Board experience with the 1950 standards, and upon changed economic conditions. Though there was disagreement among the members of the Board as to the extent of the policy changes involved, there is little doubt that some change in policy was intended; unlike the 1950 standards, these standards did not purport to be merely a restatement of what the Board had previously done. ${ }^{33}$ The studies upon which the new standards were based were carried out by a committee of legal assistants to the Board members, but again, apparently, without the benefit of public participation. The standards were never published in the Federal Register or the Code of Federal Regulations, and they were made effective "immediately." Anyone looking at the press releases would find it difficult, if not impossible, to advance any rational distinction between their contents and the contents of rules and regulations which regularly appear in the Federal Register and later find their way into the Code of Federal Regulations.

Apparently the members of the Board did not believe that they had engaged in rule-making. In any event, when the first decision applying the new standards finally issued on October 24, 1954,34 although one of the two dissenting members argued that the Board had mistakenly taken on a legislative function, none of the opinions discussed the necessity of compliance with, or at least exemption from, the rule-making requirements of the Administrative Procedure Act.

This episode in the 1954 change of jurisdictional standards should be noted in evaluating the Board's claim that the broad public participation involved in rule-making would involve delay and diffusion of issues in disposition of specific cases. Activities which certainly appear to have been rule-making were completed on July 15, whereas the first adjudication involving those same principles did not appear until more than three months later! At least in this area, then, the 30 day waiting period before A.P.A. rules can become effective would be at most a slight hindrance to Board operations.

The Board revised its jurisdictional standards again in October, 1958. The action was expressly explained as a consequence of the Supreme Court decision in Guss v. Utah Labor Relations Board," which had created a "no-

32. NLRB Press Releases R-445, -449, 34 L.R.R.M. 75 (1954).

33. The first decision of the Board announcing and applying the new jurisdictional standards was Breeding Transfer Co., 110 N.L.R.B. 493, 35 L.R.R.M. 1020 (1954). The majority spoke of "revision" of the old standards, and of "our new jurisdictional policy." According to its estimate, the changes made in the standards would reduce the Board's case load by no more than 10 per cent and, in terms of employees, would affect no more than 1 per cent of the total number of employees subject to the broadest reach of the agency's jurisdiction.

34. Ibid.

35. 353 U.S. 1 (1957). The Board's announcement of its 1958 standards stated, "We are taking this action as a consequence of the situation to which the Supreme Court referred in the case of Guss v. Utah Labor Relations Board. Therein the Supreme Court adverted to 'a vast no-man's land, subject to regulation by no agency or court,' and de- 
man's land" where recourse to neither state nor federal law was possible. The change clearly constituted a substantial alteration in Board policy. Adoption of the new standards was preceded this time by the issuance of a press release in July setting forth the proposed standards, establishing September 1, 1958, as the intended effective date, and inviting comments by interested persons. ${ }^{36}$ On October 2, 1958, one month after the previously announced intended effective date, the Board issued another press release announcing the revised standards, and giving them "immediate effect." 37 Neither of those press releases were published in the Federal Register as notices of proposed rulemaking under the Administrative Procedure Act. Nor have the standards found their way into the Code of Federal Regulations, as would have been the case if there had been compliance with the Administrative Procedure Act. A Board decision discussing the adoption of the new standards did not appear until a month and a half later, on November $14,1958 .{ }^{38}$ The decision, filed in a representation case, laid down Board policy for an entirely different problem, one presented in unfair labor practice cases: whether the new standards should apply to unfair labor practices which allegedly occurred when an employer was not subject to regulation under the then existing standards. It was decided that a retroactive effect should be given to the new standards, subjecting to Board sanctions conduct which did not appear to be regulated when it occurred.

Since that time there has been another, more particularized, change in the Board's jurisdictional standards. The Board now accepts cases involving the hotel industry which had previously been subject to a blanket exemption. Like the general 1958 change this change was frankly acknowledged to be in response to a Supreme Court decision ${ }^{39}$ it thus constituted a change in agency policy. However, the press release ${ }^{40}$ announcing the proposed standards for Board assertion of jurisdiction with respect to hotels, and inviting interested parties to file briefs or comments, was not published in the Federal Register. The final standards, which also took "immediate effect," were again announced in a press release ${ }^{41}$ which was not published in the Federal Register, and they have not appeared in the Code of Federal Regulations.

These revised standards, promulgated without the support of the Board's statutory rule-making powers or compliance with the provisions of the Ad-

clared: (1) 'Congress is free to change the situation;' and (2) 'The National Labor Relations Board can greatly reduce the area of no-man's land by reasserting its jurisdiction....'

"Today, we are announcing this action, so that more individuals, labor organizations and employers may invoke the right and protections afforded by the statute." NLRB Press Release R-576, October 2, 1958, 42 L.R.R.M. 96 (1958).

36. NLRB Press Release R-570, July 22, 1958, 42 LAB. REL. REP. 363 (1958).

37. NLRB Press Release R-576, October 2, 1958, 42 L.R.R.M. 96 (1958).

38. Siemons Mailing Service, 122 N.L.R.B. 81, 43 L.R.R.M. 1056 (1958).

39. Hotel Employees Local 255 v. Leedom, 358 U.S. 99 (1958).

40. NLRB Press Release R-586, January 11, 1959, 43 LAB. ReL. Rep. 233 (1958).

41. NLRB Press Release R-610, May 14, 1959, 44 Lab. ReL. REP. 70 (1959). 
ministrative Procedure Act, have received congressional ratification in the Labor Management Reporting and Disclosure Act of $1959 ; 42$ thus, if they were ever subject to attack, they are probably beyond the point of challenge today. ${ }^{43}$ Yet, one hesitates to think of the confusion and injustice which would have resulted had it been held that the Board's failure to comply with the Administrative Procedure Act provided a defense to one charged with an unfair labor practice falling within the areas affected by the 1954 or 1958 changes in jurisdictional standards.

\section{Contract-Bar Rule-Making}

The Board's contract-bar doctrine is another instance of rule-making without use of the NLRB's statutory rule-making powers or compliance with the requirements of the Administrative Procedure Act. Briefly stated, this doctrine is one which the Board evolved, without express statutory authority, to determine when it would disrupt an established collective bargaining relationship by holding an election upon the petition of a rival union. In those instances in which the Board concludes that emphasis must be given to preserving the stability of an existing collective bargaining relationship, a current contract between the employer and the incumbent union constitutes a "bar" to the election; in other situations the weight to be given employee freedom of choice leads to a conclusion that the contract should not constitute a "bar."

42. Section 701 (a) of the act, 73 Stat. 541 (1959), 29 U.S.C. $\$ 164$ (Supp. I, 1959), dealt with the no-man's land problem discussed note 30 supra, by adding a new subsection to section 14 of the NLRA. It cedes jurisdiction to state courts and agencies of those labor disputes which the Board declined to assert its jurisdiction, with a proviso that the Board may not decline to assert jurisdiction over any labor dispute over which it would have asserted its jurisdiction under the standards prevailing upon August 1, 1959. The changes discussed above had all been accomplished by that date, and thus were given congressional approval in this section.

The language of the new subsection is:

The Board, in its discretion, may, by rule of decision or by published rules adopted pursuant to the Administrative Procedure Act, decline to assert jurisdiction over any labor dispute involving any class or category of employers, where, in the opinion of the Board, the effect of such labor dispute on commerce is not sufficiently substantial to warrant the exercise of its jurisdiction: Provided, That the Board shall not decline to assert jurisdiction over any labor dispute over which it would assert jurisdiction under the standards prevailing upon August 1, 1959.

The recognition thus given to establishing standards by rule of decision might be taken as approval of the procedures used by the Board in developing its former standards. But the reference to the Administrative Procedure Act also suggests that in appropriate situations Congress would desire the Board to proceed according to the provisions of that Act. Furthermore, section 606 of the Labor-Management Reporting and Disclosure Act of 1959, 73 Stat. 540 (1959), 29 U.S.C. \& 526 (Supp. I, 1959), specifically provides that the provisions of the Administrative Procedure Act shall be applicable to the issuance, amendment, or rescission of any rules or regulations, or any adjudication, authorized by the provisions of the 1959 Act.

43. See notes 103-08 infra and accompanying text. Rules establishing jurisdictional standards might have been considered "procedural" and hence exempt by section 4(a) of 
On March 28, 1958, again by press release, ${ }^{44}$ the Board invited interested parties to submit briefs on a number of pending cases, clearly indicating that it was considering revising the then current contract-bar doctrine. At a later date, but in advance of argument in the case, the Board made public the various views expressed in the briefs filed. ${ }^{45}$ In doing so, of course, it commendably went beyond the limited requirements for public participation which are found in the Administrative Procedure Act. In June, 1958, the Board held a two-day hearing at which it heard the arguments of interested parties. ${ }^{40}$ Not until September, 1958, did the Board issue a series of decisions setting forth its revised contract-bar rules. ${ }^{47}$

The cases selected as the vehicles for announcement of these new rules were thus held pending for an extended period of time. No doubt the parties to those cases would agree with the Board's conclusion that "broad public participation involves delay and diffusion" which is incompatible with the disposition of cases on an ad hoc basis. They might, however, also point out that if the Board had adopted A.P.A. rule-making procedures it could have decided their cases under the former rules, which were not intolerable, and thus have avoided the inevitably unsettling effect that pending elections have upon labor relations and production. It is doubtful that they believed that preservation of the fiction that the Board does not engage in rule-making, but instead exercises only quasi-judicial functions in deciding particular cases, justified the turmoil and uncertainty to which they were subjected.

For fiction it clearly was to anyone reading the cases. For example, the Board's decision in Deluxe Metal Furniture Co..$^{48}$ involved the abandonment of a principle known as the General Electric X-Ray doctrine, which the Board

the Administrative Procedure Act, 60 Stat. 237 (1946), 5 U.S.C. $\$ 1003$ (a) (1958), but this is unlikely considering their substantive importance. Nevertheless, the standards have been so considered by NLRB's Committee on Revision of Rules and Regulations and Statements of Procedure. Section 2.32, Recommended Rules of Practice, published as a special supplement to the Labor Relations Reporter, July 18, 1960. They might also be considered "interpretative rules" and thus exempt under the same section of the Administrative Procedure Act. Cf. Gibson Wine Co. v. Snyder, 194 F.2d 329 (D.C. Cir. 1952). But again their use as the substantive governing rule rather than as a guide to that rule precludes such a classification.

It is of interest that in its decision in Guss v. Utah Labor Relations Board, 353 U.S. 1 (1957), the Supreme Court specifically pointed out that it was not passing upon the validity of any declination of jurisdiction or of any set of jurisdictional standards. $I d$. at 4 .

44. NLRB Press Release W-549, March 28, 1959, p. 6, 41 LAB. REL. REP. 459 (1957).

45. 42 LAB. ReL. REP. 135 (1958).

46. 42 LAB. REL. REP. 223 (1958).

47. Keystone Coat, Apron \& Towel Supply Co., 121 N.L.R.B. 880, 42 L.R.R.M. 1456 (1958) ; Hershey Chocolate Corp., 121 N.L.R.B. 901, 42 L.R.R.M. 1460 (1958) ; Deluxe Metal Furniture Co., 121 N.L.R.B. 995, 42 L.R.R.M. 1470 (1958) ; Pacific Coast Ass'n of Pulp \& Paper Mfrs., 121 N.L.R.B. 990, 42 L.R.R.M. 1477 (1958); Appalachian Shale Prods. Co., 121 N.L.R.B. 1160, 42 L.R.R.M. 1506 (1958) ; General Extrusion Co., 121 N.L.R.B. 1165, 42 L.R.R.M. 1508 (1958).

48. 121 N.L.R.B. 995, 42 L.R.R.M. 1470 (1958). 
had applied for more than twelve years. ${ }^{40}$ The Board went further than simply "legislating" this change in policy; dealing with many hypothetical fact situations which could not conceivably have been involved in the particular case, the Board announced in considerable detail the applicable rules under the new policy. ${ }^{50}$ Other cases announcing other changes in the contract-bar doctrine likewise ranged far beyond the issues involved. Indeed, the results in some of the cases which served as vehicles for announcement of the new policies were the same as they would have been if the old rules had not been abandoned. ${ }^{51}$

In the Deluxe Metal Furniture Company case, however, the petitioning union was not so fortunate, and accordingly urged the Board that it make its doctrinal changes prospectively effective, avoiding thereby a retroactive application of the new rules barring an election. To this suggestion the Board said:

[T] o adopt these revisions of contract-bar policy and then allow the instant proceeding as an exception without permitting a similar exception to all pending cases would be inequitable. To establish an in futuro rule for all pending cases would create an administrative monstrosity. The judicial practice of applying each pronouncement of a rule of law to the case in which the issue arises and to all pending cases in whatever stage is traditional and, we believe, the wiser course to follow. ${ }^{52}$

49. The doctrine was first expounded in General Elec. X-Ray Corp., 67 N.L.R.B. 997, 18 L.R.R.M. 1047 (1946). According to that doctrine, a contract executed by an employer with knowledge that a rival union claimed to represent the employees involved did not bar an election if the rival union filed a petition for an election within 10 days after making the claim. In the Deluxe Metal Furniture case, the Board decided that it would not give such effect to bare claims of interest in employees, but instead would process only petitions filed during the period falling within 150 days but more than 60 days prior to the termination date of an existing contract or filed before the execution of a new contract if none were existing.

50. Thus the Board announced what rule it would apply when a new contract was executed and a petition filed on the same day, though this was not the fact pattern in the case at hand. It stated that midnight would be the cutoff time for determining when a contract was signed even though execution was the result of continuous bargaining commencing before midnight. It stated what its policy would be with respect to processing petitions which were prematurely filed under the new rules it had just adopted. It stated what would be treated as the terminal date of a contract of "unreasonable duration" though it did not find the contract involved to be governed by that rule. The rules were also laid down for the effect to be given contracts prematurely extended by the parties during the original term, the effect to be given late notices of a desire to modify an existing contract, the effect to be given mid-term modifications of contracts, as well as the effect which would be given contracts prematurely terminated, though, of course, none of these inconsistent fact patterns were involved.

51. Keystone Coat, Apron \& Towel Supply Co., supra note 47; General Extrusion Co., supra note 47. Two other cases presented the novel situation in which one of the new rules announced would have produced a different result, but another of the new rules restored the former status of the contract as a bar. Pacific Coast Ass'n of Pulp \& Paper Mfrs., supra note 47; Appalachian Shale Prods. Co., supra note 47.

52. 121 N.L.R.B. at 1006-07; 42 L.R.R.M. at 1477. 
Of course, the inequity of denying an exception to all pending cases, as well as the "administrative monstrosity" which the Board feared it might create, could have been avoided were the Board not wedded to the fiction that it acts in a quasi-judicial capacity alone. A rule could have been adopted which would not have affected pending cases or existing contracts, but which would have been applicable instead only to those cases arising under contracts executed thirty days after publication of the new rule in the Federal Register. It is probably to be regretted, for the history of colorful expression, that the Board's rules did not permit the petitioning union to file as an appendix to the Deluxe opinion its description of what sort of a "judicial" creation the Board had spawned in a decision which devoted seven pages to a hypothetical discussion of how it would decide cases involving other parties and other facts, and only four pages, including those dealing with the argument on retroactivity, to the case at hand.

Until quite recently it appeared that the Board had exceptional freedom in developing and changing the rules, such as its contract-bar doctrine, which it applies in representation cases, ${ }^{53}$ because of a peculiar immunity from judicial review. Direct judicial review was precluded-so the view went-because the National Labor Relations Act evinces a scheme for channeling all review of questions which arise in the determination of a bargaining representative to the judicial review arising from an employer's refusal to bargain with a newly selected representative. ${ }^{.4}$ Of course this avenue of review was not open to a union defeated in an election. It thus provided no remedy to a union which believed that its contract with an employer had not been given proper effect as a bar to the election of another union. If the union whose contract was held not to be a bar won the election it continued to be the bargaining agent of the employees and the question became moot. Thus, only employers were believed to be in a position to challenge Board action on contract-bar matters.

However, the recent Supreme Court decision in Leedom v. Kyne ${ }^{55}$ has probably destroyed this supposed immunity to judicial review. There, in a representation case, the Supreme Court held that a Federal District Court had jurisdiction under the general provisions of the Judicial Code ${ }^{56}$ to correct Board action which had admittedly been taken in violation of the statutory

53. Representation cases are those in which the Board upon petitions properly filed proceeds under the powers conferred upon it by section 9 of the NLRA, 61 Stat. 143 (1947), 29 U.S.C. $\$ 159$ (1958), to determine what constitutes an appropriate unit of employees for the purposes of collective bargaining, and, to hold elections to determine which, if any union, represents the employees in that unit. They are to be distinguished from the trial of charges of unfair labor practices which are defined by section 8 of the Act and as to which the Board proceeds under the powers conferred upon it by section 10 of the Act.

54. AFL v. NLRB, 308 U.S. 401 (1940); cf. Switchmen's Union v. National Mediation Bd., 320 U.S. 297 (1943) ; Inland Empire Dist. Council v. Millis, 325 U.S. 697 (1945).

55. 358 U.S. 184 (1958).

56. 62 Stat. 931 (1948), 28 U.S.C. § 1337 (1958). 
provisions. ${ }^{57}$ This was viewed as action taken in excess of delegated powers, and hence action outside the jurisdiction of the Board. It was said not to be "review" of Board action in the sense of that term as used in the National Labor Relations Act. ${ }^{58}$

Accordingly, it is possible to give Leedom v. Kyne a limited reading, making it applicable only where the Board acts in excess of statutory authority. By this view it would provide no check upon Board action taken with respect to nonstatutory Board developed doctrine such as that of the contract bar. On the other hand, it is difficult to believe that any statute has conferred the power upon an agency to act arbitrarily or capriciously with respect to the interests of the private parties appearing before it. Thus, Board action which can be labeled arbitrary or capricious might be said to be action in excess of statutory authority, outside the jurisdiction of the Board, and hence subject to direct review under the principle of Leedom $v$. Kyne. Or, since Leedom v. Kyne establishes the proposition that the National Labor Relations Act does not preclude judicial review, arbitrary and capricious action might be set aside under the provisions of section 10 of the Administrative Procedure Act.50

Recent decisions of the Court of Appeals for the District of Columbia in cases involving direct review of Board action by the district court clearly point the way to review of contract-bar determinations in the guise of determining whether the agency decision was within the discretionary powers conferred upon the Board by the statute. ${ }^{60}$ Indeed, its recent decision in Leedom

57. NLRA, § 9(b), 61 Stat. 143 (1947), 29 U.S.C. $\$ 159$ (b) (1958), provides that ". . . the Board shall not (1) decide that any unit is appropriate for such purposes [of collective bargaining] if such unit includes both professional employees and employees who are not professional employees unless a majority of such professional employees vote for inclusion in such unit ...."

The Board included nine nonprofessional employees in a unit with 233 professional employees because, while the nine were not professional employees, they "share[d] a close community of employment interests with [the professional employees, and their inclusion would not] destroy the predominantly professional character of such a unit." 358 U.S. at $185-86$.

58. Id. at 188.

59. 60 Stat, 243 (1946), 5 U.S.C. $\S 1009$ (1958). The pertinent language is: "Except so far as (1) statutes preclude judicial review or (2) agency action is by law committed to agency discretion [a reviewing court] (e) ... shall ... set aside agency action, findings, and conclusions found to be (1) arbitrary, capricious, an abuse of discretion, or otherwise not in accordance with law ...."

If the introductory words "Except so far as" are given a literal reading rather than treated as the equivalent of "except when," the Administrative Procedure Act provides no basis for review beyond that established by Leedom $v$. Kyne itself. See 4 Davrs $\S 28.08$, at $33-42$.

60. Leedom v. IBEW, 278 F.2d 237 (D.C. Cir. 1960); Toolcraftsmen v. Leedom, 276 F.2d 514 (D.C. Cir. 1960), petition for cert. filed, 46 LAB. REF. REP. 403 (May 27, 1960, No. 108) ; Leedom v. Norwich Conn. Printing Specialties, 275 F.2d 628 (D.C. Cir. 1960); National Biscuit Division v. Leedom, 265 F.2d 101 (D.C. Cir. 1959), cert. dentied, 359 U.S. 1011 (1959) ; cf. Connecticut Light \& Power Co. v. Leedom, 174 F. Supp. 171 (D. D.C. 1959). 
v. International Bhd. of Elec. Workers ${ }^{61}$ upholds the validity of one of the changes in the contract-bar rules made in September, 1958. The change involved the Board's replacement of its former rule that a contract with a term of five years or less would bar an election if a substantial part of the industry involved was covered by contracts of a similar term. The new rule provides that in no event may a contract be a bar for a term of more than two years. The conclusion of the court was characterized by the author of its decision as one "reached with considerable difficulty." Upon balance of competing claims, the court held retroactive application of the new rule constitutional. The Board's argument that otherwise it would be precluded from giving the new rule full effect for up to five years appeared particularly persuasive, and perhaps presents a stronger case for retroactivity here than can be supplied with respect to other changes in the contract-bar rules. While the opinion ends with a statement that review by way of an original equity suit in the district court will not lie, perusal of the opinion leaves little doubt that review was had upon the merits.

Leedom v. Kyne also provided the jurisdictional basis for a successful attack upon another of the new contract-bar doctrines in a suit brought in the District Court for the Eastern District of New York. ${ }^{62}$ The court concluded that the broad proposition formulated by the NLRB in the announcement of its new doctrine failed to give weight to distinguishing factors in the case at bar, and accordingly it issued an injunction nullifying the election that had been held upon the petition of a rival union. In neither this opinion nor in the opinion of the Court of Appeals for the District of Columbia was there a discussion of whether failure to comply with the rule-making requirements of the Administrative Procedure Act invalidated the recently announced contract-bar changes. ${ }^{63}$

\section{Rule-Making in Unit Determinations}

The Board has engaged in a less obvious, and perhaps more defensible, rule-making with respect to rules governing the severance of units of skilled craftsmen from larger bargaining units of all production and maintenance employees. This troublesome area is one in which difficulties were magnified because of the competing interests of AFL and CIO unions on the one hand, and divergent management views concerning the desirability of dealing with one or several unions on the other.

Under the original Wagner Act the Board had decided that, if there had been no prior history of bargaining upon a craft basis, it would not ordinarily allow the severance of a unit of craft employees from a larger existing unit with a substantial history of bargaining. ${ }^{64}$ In the Taft-Hartley amend-

\footnotetext{
61. 278 F.2d 237 (D.C. Cir. 1960).

62. Local 476, Industrial Workers v. McLeod, 46 LAB. REL. REP. 2454 (E.D.N.Y.

63. See notes 103-07 infra and accompanying text.

64. See American Can Co., 13 N.L.R.B. 1252 (1939).
} 1960). 
ments a limitation was imposed upon the Board's power to refuse to grant craft severance elections. Section 9 (b) (2) of the Act was amended to provide that:

the Board shall not .... (2) decide that any craft unit is inappropriate for such purposes [of collective bargaining] on the ground that a different unit has been established by a prior Board determination, unless a majority of the employees in the proposed craft unit vote against separate representation .... ${ }^{65}$

In 1948 the Board issued its decision in the National Tube case. ${ }^{00}$ It gave a strict and literal reading to the amendment, which by its terms prohibits denial of craft severance only upon the basis of a prior Board determination establishing a different unit. Accordingly, the Board held that due to the integrated nature of operations, as well as the history of bargaining upon a broader basis, it would not authorize separate craft units in the basic steel industry. This same conclusion was later reached with respect to the wet milling, ${ }^{67}$ lumber, ${ }^{68}$ and aluminum industries. ${ }^{69}$

In 1954 the Board announced a change in policy in its American Potash decision. ${ }^{70}$ Section 9 (b)(2) was given a broader reading as favoring the principle of craft severance. Accordingly, the Board stated that it would not extend the practice of denying craft severance on an industry-wide basis. This led to an abandonment of the Board's former rule-making practice whereby determinations about the nature of an industry as a whole accompanied decisions on petitions for individual units with separate craft status. The Board, however, preserved the industry-wide rules which it had previously adopted by stating that it would continue to decline to entertain petitions for craft severance in the industries to which the National Tube doctrine had already been applied. Moreover, the announcement in American Potash of future policy with respect to the severance of craft and departmental units in other, unrelated, cases itself constituted rule-making activity by the Board.

Both facets of the rule-making accomplished in the American Potash decision were recently subjected to the critical review of the Court of Appeals for the Fourth Circuit in NLRB v. Pittsburgh Plate Glass Co. ${ }^{71}$ In that case, testing the correctness of the Board's unit determination, the employer refused to bargain with the certified representative of a unit of craft employees working in its highly integrated flat glass manufacturing plant. The Court of Appeals viewed the Board's American Potash decision as adopting a flat rule that craft units must be split off from an established industrial

65. 61 Stat. 143 (1947), 29 U.S.C. $\S 159$ (b) (2) (1958).

66. 76 N.L.R.B. 1199 (1948).

67. Corn Prod. Ref. Co., 80 N.L.R.B. 362 (1948).

68. Weyerhaetuser Timber Co., 87 N.L.R.B. 1076 (1949).

69. Permanente Metals Corp., 89 N.L.R.B. 804 (1950).

70. 107 N.L.R.B. 1418 (1954).

71. 270 F.2d 167 (4th Cir. 1959), cert. denied, 361 U.S. 943 (1960), 1960 Wis. L. REV. 683. 
unit whenever requested by a craft union, irrespective of the nature or degree of integration in the industry and the history of bargaining in that industry. This, the court thought, was in derogation of the Board's duty to decide in each case what would be the appropriate bargaining unit. While recognizing that the Board might develop its policies either by general rule or by ad hoc decisions, the court condemned as arbitrary and discriminatory the Board's action of formulating policies of general application and applying them in the same case. The court found no reasonable explanation for the Board's discrimination in favor of the four industries to which it had applied the National Tube doctrine. ${ }^{72}$ Having condemned the conflict between the Board policy determinations and its action in sometimes allowing craft representation under precisely the same circumstances in which it is at other times denied, the court denied enforcement of the Board's order.

While this appears to be the only set-back suffered by the Board thus far, the probabilities are that there will be others. Though the Court of Appeals for the Seventh Circuit recently rejected a similar attack upon the Board's action in granting craft severance, it did so upon the ground that unlike Pittsburgh Plate Glass the case before it did not involve an integrated industry and not upon the ground that the Fourth Circuit decision was erroneous. ${ }^{73}$

Some passages in the Pittsburgh Plate Glass opinion indicate that only ad hoc, individualized unit determinations would be accepted by the Fourth Circuit. ${ }^{74}$ However, its express recognition that the Board might develop its policies by general rules, ${ }^{\mathrm{T}}$ and the obvious necessity and inevitability of developing governing decisional principles, suggest that the court would have approved the use of rules of general applicability which were properly formulated in either the traditional quasi-judicial or quasi-legislative manner of administrative agencies. It appears that the Board's action was rejected because it departed so far from the judicial rule-making process in which policies are developed and changed by a slow process of accretion, prolifera-

72. 270 F.2d at 174. See notes 65-69 supra.

73. NLRB v. Weyerhaeuser Co., 276 F.2d 865 (7th Cir. 1960).

74. With respect to the exemption from craft severance established for the previousiy mentioned four integrated industries, the court said,

Its policy with respect to the four industries is solely based, so far as we can see, on its prior determination that in these industries craft representation will not be tolerated. This position is not only open to the objections hereinbefore outlined, but plainly constitutes a violation of the express provision of $\S 9(\mathrm{~b})(2)$ of the statute, which forbids the Board to decide that any craft unit is inappropriate on the ground that a different unit has been established by a prior Board determination.

270 F.2d at 175. This statement may have been directed, however, not so much at the making of broad industry policy determinations per se, but toward applying a broad industry policy determination with respect to four industries, including new plants established in those industries, while refusing, upon the basis of another broad policy determination, to consider whether conditions in the industry involved should be given similar effect.

75. 270 F.2d at 174. 
tion, and distinction of governing principles. Through blatant rule-making in a quasi-judicial proceeding the Board exposed itself to charges of arbitrariness and capriciousness. Forthright adoption of rule-making procedures under the Administrative Procedure Act, with industry-wide determinations on the appropriateness of craft severance-prospective in operation-set out as the general governing principle in the absence of special circumstances, might have succeeded where the disguise of the ad hoc method was insuffcient.

\section{Rule-Making and Hiring Halls}

Union security clauses have been similarly troublesome for the NLRB. Section 8(a) (3), as amended by the Taft-Hartley Act, permits the execution of a collective bargaining agreement requiring "as a condition of employment membership ... [in the contracting union] on or after the thirtieth day following the beginning of such employment or the effective date of such [collective bargaining] agreement, whichever is the later ...." However, a proviso to the section renders unjustifiable any discrimination against an employee for nonmembership in the union if the employer has reasonable grounds for believing that "... membership was denied or terminated for reasons other than the failure of the employee to tender the periodic dues and the initiation fees uniformly required as a condition of acquiring or retaining membership ....".76

Strict as these limitations are, after more than ten years of administering the National Labor Relations Act with its Taft-Hartley amendments the Board had not held the act violated by a contract requiring an employer to obtain all his new employees through a union controlled and operated hiring hall. Hiring halls have been a very important protection to employees from the extortion and kick-back demands that petty supervisors might exact in "shape-up" hiring on the waterfront, or in similar irregular hiring of occasional employees. For employers, hiring halls have provided pools of skilled labor, available without expensive recruiting activities. ${ }^{77}$ Avoiding a holding of illegality per se, the Board required proof that either the contract itself provided for an illegal discrimination in favor of union members, or that it was in fact being administered in a discriminatory manner favoring union members. ${ }^{78}$

In 1957, however, a majority of the Board apparently became dissatisfied with the results obtained by imposing upon the General Counsel the burden of proving actual discrimination under a hiring hall arrangement. A case now known as Mountain Pacific ${ }^{79}$ served as the vehicle for announcement of the

76. NLRA, § 8(a) (3), 61 Stat. 140 (1947), 29 U.S.C. \$ 158(a) (3) (1958).

77. Hopkins, Labor in the American Econony 33-35 (1948).

78. National Union of Marine Cooks, 90 N.L.R.B. 1099 (1950); Hunkin-Conkey Constr. Co., 95 N.L.R.B. 433 (1951).

79. 119 N.L.R.B. 883 (1957). In an earlier case involving the same contract the Board refused to pass upon the validity of the contract provisions governing hiring, but instead 
change in policy. Distortion of the traditional quasi-judicial form was perhaps indicated by the fact that a dissenting opinion, warning that a change was in the offing, was filed in December of 1957; but not until the end of March, 1958 did the majority opinion appear.

The majority view in Mountain Pacific was that a hiring hall agreement was inherently discriminatory, and that no independent evidence of discrimination was necessary to establish a violation of the Act. But the majority believed that the inherently discriminatory impact of a hiring hall agreement might be overcome if certain limitations upon the union's powers were both made express in the contract and published to prospective employees. The substance of the necessary limitations to be made in contract provisions was then set out in the opinion. ${ }^{80}$

Change in policy and abandonment of former rules are, of course, a familiar part of the judicial as well as the quasi-judicial process. However, the proffering of advice on what contract provisions would be approved in future cases, as done by the Board in Mountain Pacific, is at least a very unusual aspect of either of those processes. It has the appearance of a rule prescribing conduct for future negotiations and for contracts which are still to be executed. It seems obvious that the standards for the future were stated to avoid the flood of litigation which would otherwise have followed to test whether the announced inherent illegality of clauses such as those in the case before the Board might somehow be overcome through other express contract pro-

based its decision upon evidence of discriminatory administration of the provisions. Associated General Contractors, Inc., 117 N.L.R.B. 1319 (1957).

The Monntain Pacific standards may now have received a legislative ratification in the enactment of section 705 of the Labor-Management Reporting and Disclosure Act of 1959, 73 Stat. 545 (1959), 29 U.S.C. \$ 158(f) (Supp. I, 1959). The conference report on that section states, "Nothing in such provision is intended to restrict the applicability of the hiring hall provisions enunciated in the Monntain Pacific case, 119 N.L.R.B. at 893, or to authorize the use of force, coercion, strikes, or picketing to compel any person to enter into such prehire agreements." H. CoNF. REP. No. 1147, 86th Cong., 1st Sess. (1959).

80. The majority said:

We believe, however, that the inherent and unlawful encouragement of union membership that stems from unfettered union control over the hiring process would be negated, and we would find an agreement to be nondiscriminatory on its face, only if the agreement explicitly provided that:

(1) Selection of applicants for referral to jobs shall be on a nondiscriminatory basis and shall not be based on, or in any way affected by, union membership, bylaws, rules, regulations, constitutional provisions, or any other aspect or obligation of union membership, policies, or requirements.

(2) The employer retains the right to reject any job applicant referred by the union.

(3) The parties to the agreement post in places where notices to employees and applicants for employment are customarily posted, all provisions relating to the functioning of the hiring arrangement, including the safeguards that we deem essential to the legality of an exclusive hiring agreement.

119 N.L.R.B. at 897. 
visions. To those who believed the former rule to be correct it would also appear to be an attempt to legislate additional restrictions on the substance of collective bargaining agreements. ${ }^{81}$

The change in policy made by the Board was of major proportions since it outlawed the hiring hall provisions of many contracts, particularly in the construction industry. Condemnation of such clauses, coupled with a preexisting Board policy of requiring unions and employers to reimburse employees for all dues and fees collected under an illegal union security provision, threatened both unions and employers with enormous financial burdens. ${ }^{82}$ This would have been particularly true if the Board, following the judicial analogy, had applied the new rule to all pending cases and to all existing contracts having clauses which would have been valid under the former rule.

The Board was in very large part saved from the necessity of assessing such harsh consequences to contracts made in reliance on the former rule and on events which had already transpired..$^{83}$ Relief to unions and employers took the form of a moratorium, declared by the General Counsel of the Board, upon the processing of charges based upon illegal hiring hall clauses. His original announcement was made in February, 1958; it established June 1, 1958, as the date upon which the hiring hall clauses in existing agreements had to be brought into conformance with the new standards which the Board had not yet proclaimed! At the end of March, 1958, the Mountain Pacific majority opinion was handed down. In April, the moratorium period was extended to September 1, 1958. In August, the General Counsel announced another extension to November 1, 1958, for the benefit of those employers and unions which had made "genuine efforts" to correct their union security and hiring arrangements prior to the September 1 deadline. On November 1, 1958 the time for full compliance finally arrived. ${ }^{84}$ In form the Board had done no more than render a quasi-judicial opinion stating a change of law effective immediately upon contracts previously executed. In fact, the evils of a retro-

81. Compare, Friendly, $A$ Look at the Federal Administrative Agencies, 60 Colum. L. REv. 429, 442-43 (1960).

82. This is the Board's so-called Brown-Olds remedy, based upon the remedy ordered in Plumbers Union (Browns-Olds Plumbing \& Heating Corp.), 115 N.L.R.B. 594 (1956). The validity of this remedy is to be determined by the Supreme Court this term in cases in which certiorari has been granted to review the conflicting decisions of Courts of Appeals. Local 60, United Bhd. of Carpenters v. NLRB, cert. granted, 363 U.S. 837 (1960); Local 357, Int'1 Bhd. of Teamsters v. NLRB, cert. granted, 363 U.S. 837 (1960).

83. It does not appear that at any time during the General Counsel's "moratorium" that the Board had any occasion to decide that execution and enforcement of collective bargaining agreement with hiring hall provisions lacking the required safeguards constituted violation of the act in the absence of evidence that it was being enforced in a discriminatory manner.

84. For a summary of these developments, see the speech of Jerome Fenton, the NLRB General Counsel, before the Illinois State Bar Association's Labor Law Section. 43 I.R.R.M. 40 (1957). 
active effect of the change in law were avoided through the administrative grace of the General Counsel. In short, as to parties other than those involved in the suit the change in law was given only prospective operation; such would have been the case if the Board had engaged in rule-making under the Administrative Procedure Act, setting a delayed date for effectiveness of the new rules.

For the parties to the Mountain Pacific decision the result was somewhat different. They too were spared the heavy burden of reimbursement of fees and dues collected under the contract, though no explanation was given for this leniency. ${ }^{85}$ But their contract was declared illegal, and they were ordered to cease giving effect to it and to post notices to employees stating that they would cease their violations of law. In short, though things were not as bad as they might have been for the parties to that case, they did play the sacrificial role the Board assigns to parties whose cases are the vehicles for rulemaking activities conducted in the guise of quasi-judicial proceedings.

Upon the Board's petition for enforcement, and the respondent's petition to review, the Mountain Pacific case was taken to the Court of Appeals for the Ninth Circuit as NLRB v. Mountain Pac. Chapter of the Assaciated Gen. Contractors, $I n c .^{86}$ One of the principle arguments made by Associated General Contractors, but unmentioned in the opinion, was that the Board had engaged in illegal legislative rule-making in the course of deciding the case. ${ }^{87}$ From the failure of the court to deal directly with this argument in its opinion conflicting inferences may be drawn. Perhaps the court believed the argument to be so unsubstantial as not to be worthy of detailed consideration. On the other hand, it may have decided the case upon other grounds to avoid the difficulties of a novel and knotty question.

In any event, the Ninth Circuit viewed the matter differently than the Board. Basically, the court's disagreement with the NLRB was on the substantive issue of whether a hiring hall contract clause was legal if it did not state the required limitations upon the union's powers. The court did not believe that the limitations were necessary for legality, but believed instead that each case should turn upon its peculiar facts. The court recognized that an employer might be held to have agreed to, and to have enforced, discriminatory policies even though the contract contained no express discriminatory provisions. ${ }^{88}$ More to the point with which we have been concerned, however, the court also recognized that the Board's specialized knowledge and experience might qualify it to attach peculiar weight to a certain type of evidence and to draw an inference in a particular case that such a tacit discriminatory agreement did exist. The court said,

85. The probable reason being that the General Counsel, not anticipating a change in Board policy, had not requested such relief.

86. 270 F.2d 425 (9th Cir. 1959).

87. Brief for Mountain Pacific Chapter of the Associated General Contractors of America, pp. 17-30, NLRB v. Mountain Pacific, 270 F.2d 425 (9th Cir. 1959).

88. 270 F.2d at $430-31$. 
There seems to be no valid reason why an administrative body cannot progress from precedent to precedent. The Board has now decided, in view of its experience, that special significance must be given to the failure to include protective clauses in these contracts. But such a rule of evidence should operate prospectively, since the burden is thereby shifted. This approach cannot be upheld in the instant case. But this Court sees no reason why the doctrine once announced could not be applied in future cases. ${ }^{89}$

The cases was remanded to the Board for further consideration, apparently of the factual matter-whether the employers had intended to enter into and to enforce a discriminatory contract hiring procedure.

More recently the Board's Mountain Pacific rule has been rejected by the Court of Appeals for the Sixth Circuit in NLRB v. E \& B Breving Co."0 The Board frankly admitted in its argument that it had adopted a new "rule," and that it had abandoned the case-by-case method of determining whether the hiring hall arrangement was being enforced discriminatorily. The court, having noted that the Board did not purport to base this new rule upon the rulemaking power given to it by Section 6 of the National Labor Relations Act, bluntly stated," "Perhaps the Board might have saved itself a lot of trouble by utilizing this method of making a rule." It then proceeded to consider the Board's development of the new rule through the process of administrative adjudication. Recognizing that the Board's first interpretative decision need not be its last, and that administrative rules may be changed retroactively, the court applied the familiar test of whether the retroactive change of policy would work a hardship altogether out of proportion to the ends sought.02 It found that it would work such a hardship; accordingly, it concluded that the Board's action was " 'agency action which we are directed by $\$ 10$ of the Administrative Procedure Act to set aside as arbitrary, capricious, and an abuse of discretion." "93

What conclusions may be drawn from this resume of the Board's change of law concerning hiring halls? The substantive rule which the majority of the Board desired to establish would possibly have received more favorable treatment by the Ninth Circuit if it had been adopted in a formal rule-making proceeding under the Administrative Procedure Act. That court's comments on the retroactive application of the evidentiary rule suggest that the acceptability

89. 270 F.2d at 432 .

90. 276 F.2d 594 (6th Cir. 1960), petition for cert. filed, 46 LAB. REL. REP. 402 (U.S., July 29, 1960) (No. 211).

91. 276 F.2d at 598 .

92. See SEC v. Chenery Corp., 332 U.S. 194, 203 (1947).

93. 276 F.2d at 601 . The Court also held that lack of notice that the validity of the hiring hall agreement was in issue deprived the Board of power to pass upon the issue because section 5 of the Administrative Procedure Act, 60 Stat. 237 (1946), 5 U.S.C. $\$ 1004$ (1958), requires notice of the fact and law involved in agency adjudications. $276 \mathrm{~F} .2 \mathrm{~d}$ at 599. The Board has filed a petition for certiorari which is still pending. NLRB v. E. \& B. Brewing Co., petition for cert. filed, 46 LAB. REL. REP. 402 (U.S., July 29, 1960) (No. 211). 
of the substantive rule was certainly not increased by its retroactivity. The speculative comment of the Sixth Circuit also suggests a willingness to accept a substantive rule which is formulated in accordance with the Administrative Procedure Act and made prospective only in its application. On the other hand, the Court of Appeals for the First Circuit approved the development of the new rule, considering the effects of the change no different from those which occur when, upon further consideration, a court decides to modify its earlier views. ${ }^{94}$ The ultimate fate of the rule will soon be decided by the Supreme Court, though whether the manner of it formulation will affect the decision is a matter of speculation. ${ }^{95}$ In any event, it seems clear beyond the point of argument that the turmoil created by moratorium periods and their extensions could have been avoided by the use of such rule-making procedures.

\section{Economic Strikers and Rule-Making}

One matter upon which there was substantial agreement during the consideration of the Labor-Management Reporting and Reform Act of 1959 was the need for some action to restore the voting rights of economic strikers whose positions have been filled by replacements hired during the strike. This had been the rule applied by the Board in administering the Wagner Act. Reasoning that until the dispute was settled no one could predict which would be entitled to the job, it had allowed both strikers and replacements to vote. This Board-developed practice was rejected in the Taft-Hartley Act's addition to Section 9(c) providing that, "Employees on strike who are not entitled to reinstatement shall not be eligible to vote." 97 It soon became apparent, however, that this restriction upon voting by economic strikers placed a potent union-busting weapon in the hands of employers willing to utilize it.

Supported by President Eisenhower, the Senate Labor Committee recommended that the sentence added to the National Labor Relations Act by the Taft-Hartley amendments be deleted. ${ }^{98}$ The House proposed instead that limi-

94. NLRB v. Local 176, Bhd. of Carpenters, 276 F.2d 583 (1st Cir. 1960). The court refused, however, to enforce that portion of the Board's order applying a Brozen-Olds remedy, see note 79 supra, on the ground that to do so with conduct which was recognized to be illegal only after it had occurred would be an ex post facto penalty. $276 \mathrm{~F} .2 \mathrm{~d}$ at 586.

95. The validity of the Board's hiring hall rule is now pending before the Supreme Court in Local 357, Int'1 Bhd. of Teamsters v. NLRB, cert. granted, 363 U.S. 837 (1960). The opinion below by the Court of Appeals for the District of Columbia contains no discussion of effect of the manner in which the rule was formulated. 275 F.2d 646 (D.C. Cir. 1960). On the other hand, if the certiorari is granted on the pending petition of the Board in NLRB v. E. \& B. Brewing Co., petition for cert. filed, 46 LAB. REL. REP. 402 (U.S., July 29,1960 ) (No. 211), the later question will almost certainly be reached upon argument.

96. Rudolph Wurlitzer Co., 32 N.L.R.B. 163 (1941). The decision reversed the procedure established by the earlier case, A. Satorious \& Co., 10 N.L.R.B. 493 (1938), in which only the economic strikers were allowed to vote.

97. 61 Stat. 144.

98. See S. Rep. No. 187, 86th Cong., 1st Sess. 31-33, 56 (1959). 
tations be imposed upon the holding of elections following lawful strikes not called to obtain recognition. ${ }^{99}$ The compromise language agreed upon by the conference was:

Section 9(c) (3) of the National Labor Relations Act, as amended, is amended by amending the second sentence thereof to read as follows: "Employees engaged in an economic strike who are not entitled to reinstatement shall be eligible to vote under such regulations as the Board shall find are consistent with the purposes and provisions of this Act in any election conducted within twelve months after the commencement of the strike. ${ }^{100}$

Certainly, the specific mention of regulations suggests the use of the powers given the Board by Section 6 of the National Labor Relations Act to issue "in the manner prescribed by the Administrative Procedure Act, such rules and regulations as may be necessary to carry out the provisions of this Act." The suggestion is given additional force by Section 606 of the 1959 Act: "The provisions of the Administrative Procedure Act shall be applicable to the issuance, amendment, or rescission of any rules or regulations, or any adjudication, authorized or required pursuant to the provisions of this Act."101

The Board, however, has apparently not seen fit to utilize its substantive rule-making powers in this area. On the contrary the Board's solicitor indicated in a speech that instead the Board will proceed to develop the governing principles in the course of deciding individual cases. ${ }^{102}$ This appears to be the plan, though as the Solicitor's speech makes apparent, a considerable number of the problems involved have been exposed by the pre-Taft-Hartley experience; formulation of substantive rules, therefore, could be undertaken with some confidence.

\section{Conclusion and Evaluation}

The NLRB's view of its activities as involving only quasi-judicial functions, and not substantive rule-making, is obviously untenable. The Board has clearly

99. H.R. 8342, 86th Cong., 1st Sess., $\$ 703$ (1959), as passed by the House, 105 CoNG. REC. 15892 (1959).

100. Labor-Management Reporting and Disclosure Act of 1959, $\S 702,73$ Stat. 542 (1959), 29 U.S.C. \& 159 (Supp. I, 1959).

101. 73 Stat. 540 (1959), 29 U.S.C. \& 526 (Supp. I, 1959).

102. Address of James V. Constantine, Briefing Conference of the Federal Bar Association and the Bureau of National Affairs, Inc., December 10-11, 1959, 45 LAB. REL. REP. 231 (1959). See also 46 Analysis 41.

The solicitor apparently finds support for the case-by-case approach in some remarks of Senator Kennedy during the Senate debate. In doing so, he appears to have overlooked the statement of Senator Case of South Dakota, who made the amendment upon which Senator Kennedy was commenting, that the amendment "put in the hands of the National Labor Relations Board the power to issue regulations consistent with the act, which would define the period of time and the status of the striker who could vote." 105 Cong. REc. 6533 (1959) (remarks of Senator Case of South Dakota). In any event, the debate was directed toward language found in the Senate bill before the compromise language of the act was adopted. 
abandoned the quasi-judicial approach, and has engaged in substantive rulemaking with respect to the standards governing the exercise of its jurisdiction. It likewise adopted substantive rule-making as the means of promulgating its revised contract bar doctrine. That rule-making has in fact been the process with respect to craft severance in representation cases, or with respect to the limitations upon hiring hall agreements, is somewhat less certain, but here too such a conclusion might legitimately be reached. The Board's view that the role which it performs is one to which the rule-making process is not well adapted is patently unsound. That process is exactly what the Board has used in at least two, and possibly four, major areas of its work. Indeed, the sub rosa formulation of rules in the guise of ad hoc decisions is eloquent testimony to the necessity of utilizing rule-making powers for effective discharge of the Board's obligations.

Brief consideration of the work load imposed upon the Board will make apparent the impossibility of an $a d$ hoc approach to the problems with which it deals. Codification and standardization of its substantive rules is a matter of necessity. During the fiscal year 1959, 12,239 charges of unfair labor practices were filed in the Board's twenty-five regional offices. After investigation the General Counsel issued complaints in 2,101 cases involving unfair labor practice charges. During the same year 9,347 petitions were filed for elections to determine the representative status of unions. The five members of the Board issued formal decisions in 2,883 cases, of which 764 were the relatively complicated unfair labor practice cases. At the end of fiscal 1959 the number of cases of all types pending at all procedural levels was 7,655. ${ }^{103}$ By comparison, the nine members of the United States Supreme Court disposed of only 1,787 cases during the 1959 term; they wrote full opinions in only 115 cases. The Court had only 356 cases remaining on its docket at the end of the term. ${ }^{104}$

An agency with a case load as large as that of the NLRB is understandably under great pressure to state the full implications of any new development or any departure from former precedents, even though such an explanation is not necessary to disposition of the immediate case. To do otherwise is to invite additional litigation to determine the extent of the new Board policy. And in the area regulated by the NLRB, clients are notably eager to have counsel experiment freely in determining the fullest limits of their powers and the exact restrictions imposed upon the use of the weapons available to those whom they view as economic adversaries. Changes occur frequently, if not through amendment of the statute, through adoption of a new agency policy or accommodation of agency policy to the mandates of reviewing courts. If new policies are to be expressed in the piecemeal form of statements no broader than those necessary to disposition of the immediate case, the caldron of litigation becomes a nightmare version of that magic soup-producing pot of nursery tales which flooded the streets of the town. Moreover, the sizeable field staff

103. 24 NLRB ANN. REP. 1-2 (1959).

104. The Supreme Contt, 1959 Term, 74 Harv. L. Rev. 95,99 (1960). 
must be instructed in the new policies so that the tremendous pending case load will not have to be sent back for reprocessing after it reaches the Board level. Finally, the Board deals with a vast number of cases involving similar problems; unlike a body having only individualized and isolated contacts with those problems it is in an especially propitious position to issue pronouncements involving broad generalizations.

The question remaining is whether the Board's sub rosa rule-making is a viable alternative to use of the procedures set forth in the Administrative Procedure Act. Not a small element to be weighed is the possibility that the Board's present rule-making activity is a violation of, rather than an alternative to, those rule-making provisions. One does not lightly reach the conclusion that a major agency of government has been operating in violation of the provisions of the Administrative Procedure Act. But if the proposition is taken as proved, what are and have been the consequences? Beyond our concern for even technical departure by governmental authorities from the standards established by law, the immediate threat is that important programs of the NLRB, affecting a multitude of employee, union, and employer interests, may be upset and invalidated upon court review.

The Administrative Procedure Act provides a statutory basis for invalidating rules adopted without conformance to the standards established by that Act. Section 3(a) of the Act ${ }^{105}$ expressly requires publication in the Federal Register of "substantive rules adopted as authorized by law and statements of general policy or interpretations formulated and adopted by the agency for the guidance of the public." It further provides: "No person shall in any manner be required to resort to organization or procedure not so published."

Section 4 of the Act requires that notice of proposed rule-making be published in the Federal Register, and that interested persons be afforded an opportunity to participate in rule-making through presentation of written data, views, or arguments. ${ }^{106}$ Section $10(\mathrm{e})$ of the Administrative Procedure Act offers a sanction against a short-cutting of this procedure; it provides that a reviewing court shall

... hold unlawful and set aside agency action, findings, and conclusions found to be ... (4) without observance of procedure required by law..$^{107}$

At least one Court of Appeals has held that failure to publish a regulation in the Federal Register rendered it invalid even as to one having actual notice of the regulation. ${ }^{108}$ Professor Davis is critical of the decision, ${ }^{108}$ and,

\footnotetext{
105. 60 Stat. 238 (1946), 5 U.S.C. \& 1002 (a) (1958).

106. 60 Stat. 238 (1946), 5 U.S.C. $\$ 1003$ (1958).

107. 60 Stat. 244 (1946), 5 U.S.C. \& 1009 (e) (1958).

108. Hotch v. United States, 212 F.2d 280 (9th Cir. 1954).

109. 1 DavIS $\$ 6.10$.
} 
as he points out, other courts have taken a different view..$^{110}$ On the other hand, the Court of Customs determined in a recent decision ${ }^{111}$ that a finding under the Antidumping Act of 1921 that dumping had in fact occurred constituted rule-making for the purposes of the Administrative Procedure Act. Having reviewed the existing authorities, the court concluded that failure to publish notice of the intended rule-making in the Federal Register ${ }^{112}$ invalidated the finding even as to a party who had actual notice of the proceedings and had in fact participated in them. Noting that the principle of prejudicial error had been incorporated in the review provisions of the Administrative Procedure Act, the court concluded that the purpose of that incorporation was not to repeal the express requirement that notice of intended rule-making be published. ${ }^{113}$ Contemplation of the chaos and confusion, the frustration of legitimate private interests, and the calamitous sacrifice of public interest in labor matters which would result from a similar decision with respect to any one of the major areas of NLRB activity discussed above strongly counsels against doubtful circumventions of the rule-making provisions of the Administrative Procedure Act wherever they are applicable.

This stark possibility aside, the Board's failure to utilize rule-making proceedings presents few instances of harm clearly done or of opportunities foregone. Determination of whether an agency should proceed in the development of policy on an ad hoc basis or through the more formal route of rule-making involves the exercise of judgment on a multitude of factors; among them are the nature of the problem presented, the information available concerning that problem, the practicability of formulating from that information a principle of general applicability, the advantages to the public gained from promulgation of definitive guides, the necessity of speed in the disposition of problems, the desirability of avoiding retroactive changes of law, and the soundness or justice of the policy as developed in one manner or the other. ${ }^{114}$ Such an exercise of judgment produces no black and white distinctions; it yields instead results which are entitled to respect only as the product of an informed discretion. ${ }^{115}$

It might be thought that rules formulated pursuant to formal rule-making procedures would not receive that deference accorded rules formulated in

110. Eastern Air Lines, Inc. v. Union Trust Co., 221 F.2d 62 (D.C. Cir. 1955), rev'd on other grounds, 350 U.S. 907 (1955); Air Lines Pilots Ass'n Int'l v. CAB, 215 F.2d 122 (2d Cir. 1954); Florida Citrus Comm'n v. United States, 144 F. Supp. 517 (N.D. Fla. 1956), aff'd, 352 U.S. 1021 (1957).

111. Elof Hansson, Inc. v. United States, 178 F. Supp. 922 (Cust. Ct. 1959).

112. Required by section 4 of the Administrative Procedure Act, 60 Stat. 238 (1946), 5 U.S.C. $\$ 1003$ (1958).

113. $178 \mathrm{~F}$. Supp. at 930.

114. See Baker, Policy By Rule or Ad Hoc Approach-Which Should It Be?, 22 LAw \& Conteasp. Prob. 658 (1957). The leading case is, of course, SEC v, Chenery Corp., 332 U.S. 194 (1947).

115. Id. at 203. 
adversary proceedings and developed over time in a case-by-case process. ${ }^{110}$ But that deference, of course, would depend upon the formulation having occurred in truly adversary proceedings, and not in disguised rule-making proceedings. As has been shown, the sweeping rules which are the product of much NLRB litigation are adversary in name only.

On a more pragmatic level, it seems clear that the NLRB's reliance on the presumably ad hoc policy-making process has done harm to its own program as well as to private and public interests in general. For example, while the ad hoc approach may have been the necessary and proper means for developing early contract bar principles, it would hardly appear necessary or even appropriate to a current reformulation of those principles. The contract bar doctrines were developed by the Board apart from the statute, and were utilized without major protest for as much as twelve years. During the early years the interests of those who had to make agreements in reliance upon an unsettled law may well have been properly sacrificed; the novelty of problems in the area made certainty improbable and a flexible experimental approach desirable. The necessity of continuing the experimental approach, with its undesirable consequences upon existing relationships, appears to vanish after twelve years of experiment and experience with a problem; the Board accumulated a wealth of basic data upon which broad principles and general rules could be formulated with a certainty that formerly was lacking. In short, this was not one of those instances where, in the words of the Supreme Court, ${ }^{117}$ an ad hoc approach, with its necessarily retroactive application, could be justified because "the mischief of producing a result which is contrary to a statutory design or to legal or equitable principles ... [was] greater than the ill effect of the retroactive application of a new standard."

Also, failure to use the rule-making process may actually have a deleterious effect on the substantive standards finally formulated; these may be less sound or just, even in their future operation. For example, the Board did invite the filing of amicus briefs in the contract bar cases. ${ }^{118}$ But it is doubtful that an amicus brief, the arguments of which have been oriented to problems presented in the factual context of a particular case, could approach in value the critical analysis which might have been given to a set of rules covering the multitude of problems disposed of in the contract bar decisions, which would have been proposed by the NLRB if it had complied with the Administrative Procedure Act. Here was a golden opportunity to permit public participation in the discussion of proposed rules derived from basic data available to all in reported Board decisions. Moreover, the experience and vantage point of private parties might have enabled them to point out defects in the details

116. Cf. Skidmore v. Swift \& Co., 323 U.S. 134, 139 (1944) ; Fishgold v. Sullivan Drydock \& Repair Corp., 328 U.S. 275, 290 (1946).

117. SEC v. Chenery Corp., stpra note 114; cf. Friendly, $A$ Look at the Federal Administrative Agencies, 60 CoLUMr. L. REv. 429, 437 (1960).

118. See note 42 supra. 
of the proposed rules, or unforeseen and undesirable consequences likely to result from them. ${ }^{119}$

Indeed, viewing the Board's policy formulation activities as a whole one wonders whether amicus briefs can ever aid that agency in formulating broad and detailed policies as effectively as the wide-ranging public criticism and analysis that is possible in rule-making. The precision of the analysis and comments made must vary with the specificity of the proposal commented upon. The peculiar facts of a particular case and the issues thereby suggested in the light of former precedents must be a poor substitute for exposure of the more detailed rules under consideration. In addition, parties filing amicus briefs may well feel themselves restricted to the record compiled by others, and thus refrain from introducing additional data bearing on the question. And amici are certainly not likely to appear and offer assistance in the compilation of a record before a trial examiner.

Moreover, an agency which views as its role the formulation of policy solely upon an ad hoc basis may neglect entirely to seek the advice and comments of other interested parties in making a decision of momentous importance. Thus, the decision in the leading hiring hall case, Mountain Pacific, ${ }^{120}$ appears to have been made without the assistance of amicus briefs. To the extent that stare decisis controls agency action in subsequent, similar cases, the assistance given to the Board when policy is formulated in this manner is limited to the imagination and ability of the particular counsel who happen to be involved in the proceeding. And if, as may have been the case in Mountain Pacific, ${ }^{121}$ those counsel are not informed of the full scope of the change under consideration, even they cannot offer their best efforts.

If the foregoing observations are sound, it would appear that the NLRB's rule or policy formulating procedures have suffered from a lack of public participation, the value of which even the Board has recently recognized. ${ }^{122}$

119. For example, in Boston Gas Co., 129 N.L.R.B. No. 46 (1960), the Board held a contract invalid as a bar because its dues checkoff provision required an employee to serve notice of revocation of his dues checkoff authorization on the union in addition to his notice to the employer. According to the AFL-CIO's Industrial Union Department, adherence to this ruling will deprive almost all contracts of bar status because most unions, relying on a 1948 interpretation given by the Justice Department to the pertinent section of the Taft-Hartley Act, have negotiated contracts with provisions requiring such notification, 47 LAB. REL. REP. 1 (1960). The Board has granted a rehearing in the case, 47 LAB. REL. REP. 41 (1960).

For another example, see the order amending the proposed form for a union security clause originally suggested in Keystone Coat, Apron \& Towel Supply Co., 43 L.R.R.M. 1251 (1959). See also William Wolf Bakery, Inc., 122 N.L.R.B. 630 (1958).

120. 119 N.L.R.B. 883 (1957).

121. See note 85 supra and accompanying text.

122. See text accompanying notes $8-10$ supra. In addition to those indications that the public participation possible through acceptance of amicus briefs has been useful, comments on delegations of authority to regional directors to determine appropriate units in representation cases were solicited from various parties, NLRB Press Release R-628, September 18, 1959, 44 L.R.R.M. 465 (1959), even though such a delegation would probably 
What has been the effect of silb rosa rule-making upon its strictly quasi-judicial processes? They, too, may have suffered, though probably not to the same extent.

A principal advantage of the ad hoc approach is that it permits consideration of, and adjustment for, the individual differences and factors found in particular cases. Under the Board's current practices the parties to the proceedings selected as the vehicles for announcement of changes in policy find themselves swept into a maelstrom of argument ranging far beyond the facts of immediate concern to them. In such a situation attention is not likely to be directed to the peculiar aspects of what might otherwise be a relatively unimportant case. Confirming this suspicion is the fact that courts have found occasion to criticize the Board for its failure to consider the peculiar and distinguishing factors of particular cases involving its contract bar doctrine, ${ }^{123}$ craft severance principles, ${ }^{124}$ and hiring hall agreements. ${ }^{125}$

The flexibility and experimentation which are major virtues of the ad hoc approach appear to have been lost in the rigidity of standards announced in the supposedly ad hoc determinations. Indeed one wonders whether there would not be greater flexibility if the standards were announced in rules which through their generality, suggested the possibility of departures in compelling circumstances. Any such loss of flexibility puts off the experimentation and development supposedly enjoyed in ad hoc procedure until the next occasion upon which the quasi-judicial forms are consciously distorted in the undertaking of a new legislative program.

In addition, as has been seen, the loss of flexibility in each category of cases has also entailed a sacrifice of private interests resulting from a retroactive change in standards. The courts have upon occasion balked at approval of the retroactive changes. ${ }^{126}$ Moreover, selection of an individual case as the

be exempt as a matter of internal management or agency organization within the meaning of $\S 4$ (a) of the Administrative Procedure Act, 60 Stat. 239 (1946), 5 U.S.C. $\S 1003$ (a) (1958). The General Counsel issued an invitation to certain trade organizations and labor unions to meet with him to discuss problems in connection with implementing the amendments of the National Labor Relations Act made by the Labor-Management Reporting and Disclosure Act of 1959. NLRB Press Release R-630, October 4, 1959, 44 L.R.R.M. 521 (1959). Board Member Jenkins, serving as chairman of a committee to review Board procedures also requested views of interested parties outside the agency, NLRB Press Release R-635, though procedural rules are exempt from the rule-making provisions of the Administrative Procedure Act by $\$ 4(\mathrm{a}), 60$ Stat. 239 (1946), 5 U.S.C. $\$ 1003$ (a) (1958).

123. Local 476, Industrial Workers v. McLeod, supra note 60 .

124. NLRB v. Pittsburgh Plate Glass Co., supra note 69.

125. NLRB v. Associated General Contractors, sipra note 83; NLRB v. E. \& B. Brewing Co., supra note 87. But cf. NLRB v. Local 176, Bhd. of Carpenters, supra note 91.

126. E.g., NLRB v. Associated General Contractors, supra note 83 ; NLRB v. E. \& B. Brewing Co., supra note 87. For two additional examples of Board failure traceable to its attempt to give retroactive effect to a policy change, see NLRB v. Guy F. Atkinson Co., 195 F.2d 141 (9th Cir. 1952) ; NLRB v. International Bhd. of Teamsters, 225 F.2d 343 (8th Cir. 1955). But see NLRB v. Guernsey-Muskingum Elec. Cooperative, Inc., 47 L.R. R.M. 2260 (6th Cir. 1960) ; NLRB v. Pease Oil Co., 279 F.2d 135 (2d Cir. 1960). 
vehicle for announcing a policy change has usually resulted in substantial delay in the disposition of that case, inflicting upon the parties to that case the attendant turmoil and uncertainty which normally accompanies unsettled labor problems. ${ }^{127}$ The delay and uncertainty caused by this adherence to the judicial fiction seems particularly wasteful unless the pre-existing rules produced intolerable results. Even so, upon occasion the issuance of press releases stating new policies has given evidence that changes through rulemaking could have been accomplished with greater speed and more expeditiously than through policy formulation on an ad hoc basis. ${ }^{128}$

Finally, the question arises of whether the Board's adherence to quasijudicial forms encourages litigation by those who hope that some peculiar fact of their case will take it out of a rule, the general applicability of which is somewhat clouded by its being enshrouded in the factual context of a particular case. ${ }^{129}$ Formalized rules, of course, provide more definite guides to conduct. To the extent that parties affected by formalized rules can challenge them by direct action against the agency, ${ }^{130}$ use of the formal rulemaking process may invite more litigation than would the ad hoc policymaking process, which can be challenged only by tempting a violation of the rule with its attendant penalties. On the other hand, formal rules made specifically under the powers granted by section 6 of the NLRA might be less subject to reversal on judicial review; they could be regarded by courts as what have been called legislative rules-promulgated under a congressional grant of legislative power-and thus immune from review so long as they are within that grant of power. ${ }^{131}$ Whether ad hoc rules could gain the benefit of section 6 authorization seems doubtful, since Congress has expressly conditioned that grant of power on compliance with A.P.A. procedures. Of course, even ad hoc rules have received the benefit of deference which courts have traditionally given policy determinations based on the cumulative experience of the NLRB. ${ }^{132}$ But the Board's record with policies so formulated has not been a complete success. ${ }^{133}$ If to an appraisal of the comparative abilities of the courts and the agency there were added the factors

127. See, e.g., text accompanying notes 45,46 supra.

128. See, e.g., text accompanying notes 32,36 and 77 supra.

129. Cf. Baker, Policy By Rule or Ad Hoc Approach-Which Should It Be?, 22 LAW \& Contenip. Prob. 658, 664 (1957).

130. Cf. CBS v. United States, 316 U.S. 407 (1942).

131. American Tel. \& Tel. Co. v. United States, 299 U.S. 232 (1936) ; NBC v. United States, 319 U.S. 190 (1943); 1 Davis $\$ 5.03$, at 298-306. But cf. Addison v. Holly Hill Fruit Prods., Inc., 322 U.S. 607 (1944).

132. See, e.g., Radio Officers' Union v. NLRB, 347 U.S. 17, $48-49$ (1954); NLRB v. Seven-Up Bottling Co., 344 U.S. 344, 348 (1952) ; Republic Aviation Corp. v. NLRB, 324 U.S. 793, 800-03 (1945). For a discussion of this relationship, see San Diego Building Trades Council v. Garmon, 359 U.S. 236, 242-43 (1959).

133. E.g., NLRB v. Insurance Agents' Int'l, 361 U.S. 477 (1960) ; NLRB v. Babcock \& Wilcox Co., 351 U.S. 105 (1956); NLRB v. American Nat'1 Ins. Co., 343 U.S. 395 (1952). 
that the rule had been exposed to criticism of those to be governed by it, that it lacked retroactivity, and that it was stated in a form and generality which eliminated the suspicions of particularized justice or injustice, the result might well be a more discouraging immunity to judicial reversal. ${ }^{134}$

The possible avoidance of litigation should in itself be a substantial cause of concern for an agency which has adopted disguised rule-making procedures to avoid the burden of ad hoc litigation. In this respect, the Board's insistence that policy with respect to the voting rights of economic strikers be formulated in adjudication ${ }^{134}$ has overtones of a masochistic determination to suffer under a massive caseload.

On the Board's behalf it should be noted that other factors have operated to mitigate the consequences of its non-compliance with the provisions of the Administrative Procedure Act. The specialized nature of labor law practice and the publicity given through specialized labor reporting services to impending Board action have probably produced as much or more awareness of the intended action as is achieved by many other agencies which publish notice of intended rule-making in the Federal Register. Very few persons active or interested in the labor area are likely to have been misled by the absence of rules in the Code of Federal Regulations. Complications of substantive law are necessarily so complex that the desire for a simple code intelligible to the untrained layman must be abandoned as unrealistic. ${ }^{\mathbf{1 3 5}}$

On final evaluation, however, it appears that the Board's reluctance to utilize formal rule-making procedures constitutes an unfortunate failure to realize the advantages of the administrative process available to an agency with both quasi-judicial and rule-making powers. That failure has already involved the Board in difficulties with its substantive objectives. The possibility that an entire area of Board activity may be unsettled through its failure to comply with the Administrative Procedure Act provides a strong caution against continuance of disguised rule-making activity. An intelligent, selective adoption of rule-making procedure would aid the Board in the administration of the Act, and would ensure greater success in the achievement of its objectives.

In conclusion, a few general observations may be made on the currently debated subjects of policy formulation and judicialization of the administrative process. Unlike the Hector Memorandum, the complaint here made is not that the NLRB has failed to formulate policies or to apply those policies

134. See Jaffe, Judicial Reviezy, 69 HaRv. L. REv. 239, 272-76 (1955).

135. However, the purposes of the Federal Register Act, 49 Stat. 500 (1935), 44 U.S.C. $\$ 303$ (1958), and the Administrative Procedure Act are frustrated to the extent that administrative rules or regulations of general applicability cannot be found in the Code of Federal Regulations. Absence of a comprehensive code stating the rules, substantive as well as procedural, of any agency contributes its bit to fractionalization of the legal profession into groups of specialists, each familiar with general policy pronouncements made by a particular agency in allegedly ad hoc decisions, but unable to work into other areas of specialization. Cf. Horsky, The Washington Lawyer 95-97 (1952). 
after formulation. Indeed, the evidence is to the contrary. In the case of the NLRB then, a combination of the adjudicatory and legislative functions has not prevented policy formulation. On the contrary, the combination of functions has been of assistance in developing policies which could not have been sensibly outlined without the exploratory work done on an ad hoc basis. The details of the policies in either the contract bar doctrine ${ }^{136}$ or the jurisdictional standards surely would not have occurred to one formulating policy on an a priori basis. The same observation seems sound with respect to hiring halls. Inevitably, part of policy formulation must be given to the authority which adjudicates. Moreover, the necessity of reformulating policies which the Board has experienced in adjudication confirms Professor Jaffe's observation that the discretion used in formulating rules cannot be used but once and then put back in the box. ${ }^{137} \mathrm{~A}$ continuous, sensitive response to the problems of government is desirable on the part of the adjudicating authority. Any attempt to transfer policy formulation to another body would involve a substantial sacrifice of a coordinated approach and probably would be doomed to fail.

On the other hand, the NLRB's exclusive reliance upon an ad hoc approach, while outwardly an acceptance of judicialization of the administrative process, ${ }^{138}$ has produced grossly unsatisfactory results. Probably one would find similar results wherever the potential number of cases is large, changes are frequent, the interests regulated are militant and litigious, and an agency staff is in need of policy directives. Such a judicialization is certainly not the solution to the problems which have raised the present debate. Indeed it establishes that in at least some areas advocacy of an intelligent use of the combined powers of adjudication and rule-making, though a traditional and perhaps unexciting proposal, has a greater appeal than a novel and more drastic attack upon the problems of the administrative process.

136. See note 48 supra.

137. Jaffe, Basic Isste: An Analysis, 30 N.Y.U.L. Rev. 1273, 1285 (1955).

138. The appearance of judicialization is further heightened by the separation of the prosecutory function under the jurisdiction of an independent General Counsel. 29 U.S.C. $153(d)$. 


\section{THE YALE LAW JOURNAL}

$\begin{array}{lll}\text { VOLUMe } 70 & \text { APRIL } 1961 & \text { NUMBER } 5\end{array}$

Robert E. Hudec

Editor-in-Chief

\author{
Neale M. Albert \\ LAwrence G. GoodMan \\ DAVID M. TRUBeK \\ JERE A. Young \\ Note \& Comment \\ Editors
}

\author{
HARRISON J. GoldiN \\ Article \& Book \\ Reviewe Editor \\ SIDNEY M. WOLINSKY \\ Topics \& Case \\ Editor
}

\section{Peter R. TAft \\ Mantaging Editor}

\begin{abstract}
Hershel Y. Allerhand
Douglas R. Ayer

Charles S. Battrles, Jr.

HeNRY G. Bisgaier

JOSEPH S. BoRUS

Thomas B. Bracken

CARROLI W. Brewster

ALAN M. DERSHOWITZ

JAN DEUTSCH

Grorge B. Driesen

BenjaMIN S. DuVAL, JR.
\end{abstract}

JAMES O. FREEDMAN

James H. Gillespie

David I. Goldblatt

Wirliam S. Greenawalt

David C. Greer

JoHN P. Heinz

Algernon S. Holderness, JR.

ARTHUR P. JACOBS

PHIILIP F. JoHNson

ROBERT A. JOHNSON

LAWRENCE P. KIAAMON

ZANE KLEIN
George Lefcoe

Charles E. Lewis

John T. Marshall

James L. Mitchell

Thomas S. Nichols

Stoddard D. Platt

David A. Rosen

SinNey G. Saltz

Carol W. Trencher

AdaAr Walinsky

HARRY J. WEXIER

Marie McMahoN

Business Secretary

\section{CONTRIBUTORS TO THIS ISSUE}

Jerome H. SkoLnick. B.B.A. 1952, City College of New York; M.A. 1953, Ph.D. 1957, Yale University. Assistant Professor in Sociology and Law, Yale University.

CoRNelrus J. PECK. B.S. 1944, Harvard College; Certificate 1945, Harvard Business School; IL.B. 1949, Harvard University. Professor of Law, University of Washington. 